China Perspectives

59 | may - june 2005

Varia

\title{
Energy in China: Development and Prospects
}

\section{Pun-Lee Lam}

\section{(2) OpenEdition}

Journals

Édition électronique

URL : http://journals.openedition.org/chinaperspectives/2783

DOI : $10.4000 /$ chinaperspectives. 2783

ISSN : 1996-4617

\section{Éditeur}

Centre d'étude français sur la Chine contemporaine

\section{Édition imprimée}

Date de publication : 1 juin 2005

ISSN : 2070-3449

\section{Référence électronique}

Pun-Lee Lam, «Energy in China: Development and Prospects », China Perspectives [En ligne], 59 | may june 2005, mis en ligne le 01 juin 2008, consulté le 10 décembre 2020. URL : http://

journals.openedition.org/chinaperspectives/2783; DOI : https://doi.org/10.4000/chinaperspectives. 2783

Ce document a été généré automatiquement le 10 décembre 2020.

(c) All rights reserved 


\title{
Energy in China: Development and Prospects
}

\author{
Pun-Lee Lam
}

1 After its adoption of the open-door policy in 1978, China's rapid economic development has brought about a growing demand for energy ${ }^{1}$. The energy sector has undergone remarkable expansion. In recent years, structural reforms, market incentives, and decentralisation policies were introduced to attract foreign investment in the energy sector. In 1997, the government introduced a four-step restructuring framework for the electric power industry to be in place until 2020. In 1998, the coal, oil and gas industries were also restructured. In the current Tenth Five-Year Plan (2001-2005), entitled "Developing the West", emphasis is placed on developing energy resources (including hydropower, oil and gas) in West China and their transport to the coastal regions.

China is the world's largest and second largest producer of coal and electricity respectively. China is also a major exporter of coal and importer of oil. The energy sector plays an important role in the economy, both in terms of employment and industrial output. Major oil and power enterprises are among the largest state-owned enterprises (SOEs). But despite the remarkable growth of the energy sector, the balance between energy supply and demand is achieved at a very low level of per capita consumption; and the country remains starved for energy. In 2003 and 2004, China experienced an acute shortage of energy which severely disrupted the industrial output of the country.

3 This article first reviews the current energy situation in China. This is followed by an outline of the current industry and regulatory structures of the energy sector. Specific critical issues pertaining to the development of the energy industry are then considered. The last part of this article looks into the prospects for the energy industry. The focus of this article is to consider how these structural reforms could impact the future development of the energy industry.

Energy production and consumption 
4 At present, the electric power industry is a major user of coal and oil in China (see Figure 1). China is also a major importer of oil and exporter of coal. The pattern of energy consumption has also changed remarkably over time (see Figure 2): the proportion of coal consumption in total (primary) energy consumption decreased steadily from $94 \%$ to $66 \%$ between 1953 and 2002, while the proportion of oil consumption increased from $4 \%$ to $23 \%$ during the same period. The consumption of natural gas and hydropower has remained at a low level.

1. The energy industry in China in 2002

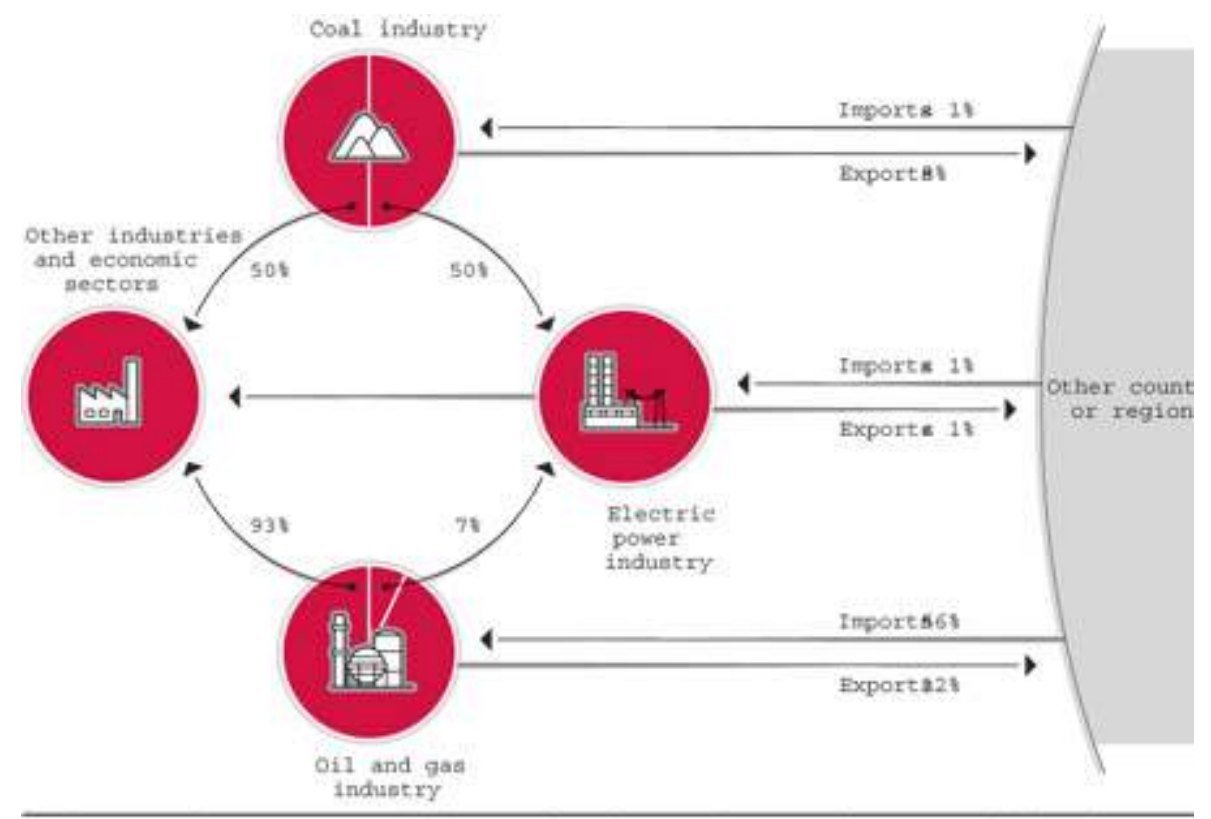

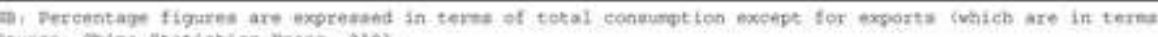
Sources Caina licat lat icul Yreas, 2003

5 Coal has remained the country's dominant indigenous source of energy. China has been exporting substantial amounts of coal and coke, and importing small quantities of coal mainly for metallurgical use. Imports might take a larger quantity with the reduction or abolition of import tariffs under the WTO and further removal of subsidies provided to state mines ${ }^{2}$. 


\section{Energy consumption in China}

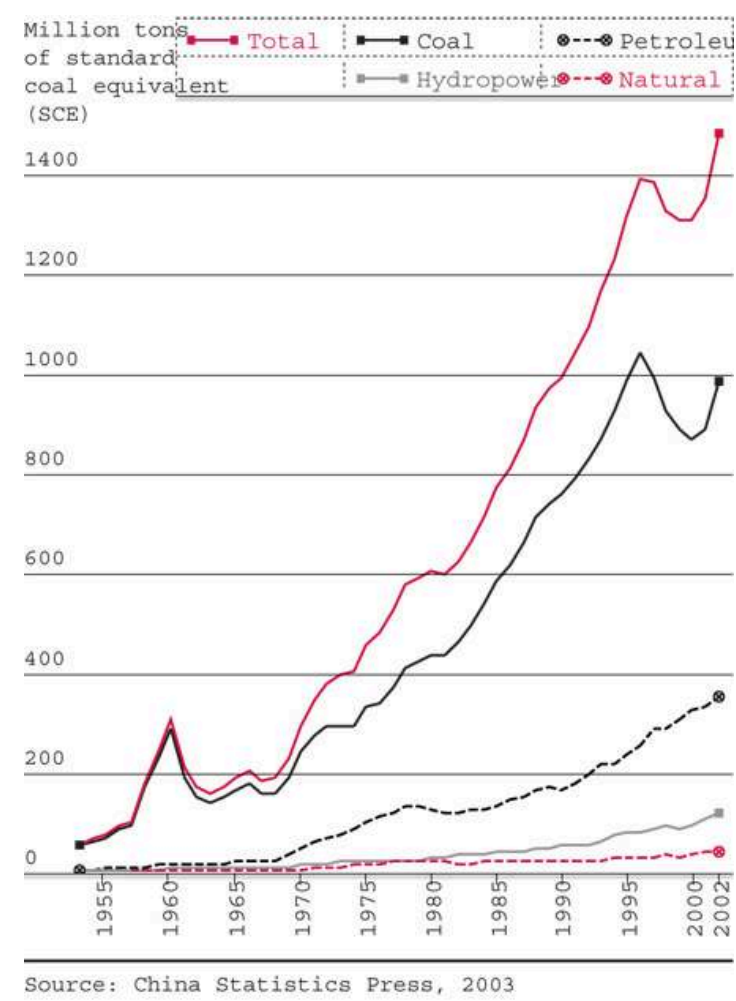

6 A fundamental problem in the coal industry is the regional imbalance between coal production and consumption. Most of the coal reserves are in the northern regions of China while most of the consumption takes place in the coastal regions. As coal producing and consuming regions are geographically distinct, adequate provision of railway and coastal shipping facilities for coal transportation is crucial ${ }^{3}$. Bottlenecks in transportation raised the costs and prices of coal and affected the shipment of other commodities ${ }^{4}$.

China's second largest energy source is oil and its share of total consumption has been growing. With the discovery of major oil fields in North China in the late 1950s, China started to produce oil on a substantial scale and production expanded rapidly during the 1960s and 1970s. In the 1980s, this expansion slowed and China suffered a drastic drop in oil export earnings as oil prices plummeted. Despite the increase in demand for oil, oil production in China has stagnated during the 1990s. As a result, China shifted from being an oil-exporting country to being a net importing country in 1993. Since then, China's external dependency for oil, measured by ratio between net imports and total consumption, has increased over time.

8 China is rich in natural gas resources, but the country produced virtually no gas before 1957. In contrast with stagnant oil production, China's natural gas production has been increasing over time. Despite its continuous growth, natural gas accounts for only $3 \%$ of the total energy production in 2003. The major consumers of natural gas now are fertiliser and chemical plants. In future, new demand for natural gas will mainly be for power generation and domestic use. By 2020 , the share of natural gas in total energy consumption is expected to increase from its current level of $3 \%$ to $8 \%{ }^{5}$.

The electric power industry is a major user of coal and oil. Since 1949, the Chinese government has placed a greater emphasis on developing the power industry. Within 
30 years, a complete system of electric power industry was built up. The industry expanded from coastal regions to the interior areas and from cities to extensive countryside. In the 1980s and 1990s, after China adopted an open-door economic policy, structural reforms, market incentives, and decentralisation policies were introduced to attract local and foreign investment in the power sector. Additional funding from the World Bank and Asian Development Bank was also available for capacity expansion.

Apart from coal, oil, gas and electric power, a major source of China's energy supply for its rural population is biomass (crop wastes and fuelwood). Most biomass fuels are used for home cooking, heating and agriculture. It was estimated that in energy terms, the volume of biomass used is approximately equivalent to that of its oil consumption. Since the 1980s, biomass use has been dropping as living standards have improved and alternative fuels have become available to rural residents. Hydro-electric power and biomass are two major renewable energy sources used in China; the application of other renewable energy sources such as solar heating and wind power are relatively insignificant.

In terms of total energy consumption, China is the second largest consumer of energy in the world behind the United States. But because of its large population, energy consumption per capita remains at a very low level (see Table 3). Energy intensity, measured as energy per capita of GDP, is high.

\section{Energy consumption in China}

\begin{tabular}{|c|c|c|c|c|c|}
\hline & $\begin{array}{l}\text { Tot } \\
\text { energy } \\
\text { (qu }\end{array}$ & $\begin{array}{l}\text { primary } \\
\text { asumption } \\
\text { rilision Bry? }\end{array}$ & $\begin{array}{l}\text { Populacion } \\
\text { (milifona) }\end{array}$ & $\begin{array}{l}\text { Der capita total } \\
\text { primary energy } \\
\text { conumption } \\
\text { (millice aru) }\end{array}$ & $\begin{array}{l}\text { Energy inten } \\
\text { GDP (Dialichenrv por Isss ps? } \\
\text { Df } 1995 \text { DSe) market exchange }\end{array}$ \\
\hline Canada & & 13.07 & 310 & 417.6 & 729.41 \\
\hline China & & 43.16 & 1.285 .0 & 33.3 & $1.117,8=$ \\
\hline France & & 10.95 & 59.5 & 183.6 & 1.809.7. \\
\hline India & & $13.9 t$ & $1,033,9$ & 13.3 & 511.61 \\
\hline Japan & & 21.97 & 127,2 & 172.3 & $5,686.41$ \\
\hline Ruasia & & 27,54 & 144.8 & 191.1 & 366,91 \\
\hline United & Statea & $98.0 z$ & 285.61 & 339.1 & $9,035.51$ \\
\hline
\end{tabular}

Structure of the energy sectorCoal

China's coal production can be divided into three main categories: state mines under central administration, local state mines, and local non-state mines. Most of the nonstate mines are small township and village enterprises (TVE, xiangzhen qiye). Before the early 1980s, the annual output of coal from state mines was well above that from local state and TVE mines. Since then, the output of TVE mines had increased rapidly and exceeded that for state mines by the early 1990s. The rapid growth of TVE mines was a result of the two-track structure of production and allocation in the coal industry.

Prior to 1993, coal users had to buy coal from their designated suppliers in volumes and at prices based on the national coal allocation plan. The central government set prices for coal lower than those in the international markets. As a result of inadequate supply of coal at low prices from state plans, TVE mines provided another source of supply on top of the over-quota production from state mines. These TVE mines competed with state mines for the coal markets and railway capacity for transportation. Unlike the state mines, TVE mines did not have to bear many of the social costs of their operations 
and other welfare responsibilities. They produced a higher level of pollution and operated at a lower level of safety. The death rate in terms of death per million tons of output in TVE mines has been higher than in state mines. Their low operating costs and rapid expansion in coal production have eroded the market share of state mines.

Starting in 1993, the national coal allocation was changed from mandatory plan to guidance plan. The coal users and suppliers could negotiate prices freely. The government also relaxed the price controls in certain provinces and regions in 1993. Price controls in all provinces and regions were removed in 1994. The government then only issued guidance prices for coal used for specific purposes, such as power generation. The removal of price controls resulted in substantial increases in coal prices.

15 To avoid price cuts on the coal market and to improve the competitiveness of state mines, the central government attempted to restrict the activities of TVE mines by introducing safety and pollution controls. In 1996, the government promulgated the Coal Law. This Law covers all aspects of coal production, including planning for resource exploitation, approval of new mines, issuance of mining and production permits, safety standards and business management. In 1998, the State Council ordered the closure of 25,000 non-state mines and 40 state mines. Some provincial governments followed by prohibiting power companies and other major users from buying from TVE mines. State mines were encouraged to merge with each other to increase efficiency, and some were transferred to a single mining group under the supervision of provincial governments ${ }^{6}$. These policies not only helped the state mines to regain market share, but have also had an impact on improving the quality and safety of coal production. In the years after the closure of many coal mines, production was able to meet growing demand and coal prices have soared.

The reorganisation of the coal industry aimed at separating the business functions of the government from its regulatory functions. In 1998, the National Coal Industry Bureau was formed under the State Economic and Trade Commission (SETC). This Bureau was responsible for industry planning and regulation and no longer directly managed the enterprises under its jurisdiction. But after two years, in 2000, the Bureau was abolished and its functions are now performed by the SETC directly 7 .

Oil and gas

17 The Chinese government considers the oil and gas industry as one of the "pillar" industries that play a leading role in the national economy. The petroleum and petrochemicals industry was organised into three segments: onshore and offshore exploration and production; manufacturing and refining operations of refined petroleum products and petrochemicals; and distribution, marketing and sales of refined petroleum products.

In 1998, the Chinese government restructured the petroleum and petrochemicals industry by reorganising the oil companies and separating the regulatory functions of the government from business functions. The oil and gas industry is now dominated by three major groups; China National Petroleum Corporation (CNPC) and its subsidiary PetroChina Company Limited (PetroChina); China Petrochemical Corporation (Sinopec) and its subsidiaries China Petroleum and Chemical Corporation; and China National Offshore Oil Corporation (CNOOC) and its subsidiary CNOOC Limited ${ }^{8}$.

CNPC and Sinopec are the only two oil and gas companies engaged in all businesses of the production chain, which include onshore crude oil and natural gas exploration, 
refining and marketing and chemical operations in China. CNPC is engaged in the exploration and production of onshore crude oil and natural gas in the northern and western regions, with Sinopec in the eastern, southern, coastal and central regions in China. CNOOC is principally engaged in offshore exploration and production. All of the oil and gas reserves in China are held by these three major groups and, among them, CNPC is the largest producer of crude oil and natural gas.

The rapid growth in oil consumption in China is related to the higher demand for refined petroleum products and petrochemicals. The increasing consumption of refined products like gasoline and jet fuel is due to the increased convenience of highway and aviation traffic. The growth in the consumption of petrochemicals is due to the growth in the domestic production of consumer products, which are made of petrochemicals. Oil is transported by pipelines, railways and waterways, while most of its imported crude oil is shipped by oil tanker to oil jetties along the coastal line of China.

The oil and gas industry is regulated by a number of agencies, the two most important among them being the State Development Planning Commission (SDPC) and the SETC. The SDPC formulates and implements most of the government policies regarding the petroleum and petrochemicals industry; it estimates production, allocates import and export quotas, publishes benchmark prices and retail guidance prices with reference to world prices, approves investment projects including Sino-foreign joint-venture projects that exceed certain limits. The SETC is responsible for co-ordinating the economic development of state-owned enterprises and overseeing their reform.

Prices of crude oil and petroleum products had been under government controls until the early 1980s; then, the government began to liberalise oil prices. Similar to the coal industry, a two-track pricing system was introduced: in-quota low prices and market prices above production quota. Price controls were gradually removed and output prices were allowed to adjust to reflect fluctuation of input costs ${ }^{9}$. Deregulation resulted in higher oil prices. In 1994, controls were re-imposed on both crude and refined products in an attempt to combat inflation. The government directly set the prices of domestically produced oil, which did not reflect international market prices.

After June 1998, the government relaxed price controls by generally allowing producers and buyers to negotiate oil prices themselves. For natural gas sold within the government-formulated plan, the Commission fixes wellhead prices. For the natural gas sold in excess of the plan, producers are allowed to set prices within $10 \%$ of the guidance price published by the Commission. Natural gas producers are also required to submit proposed pipeline transmission tariffs for examination and approval ${ }^{10}$.

Electric power

Since 1949, the electric power industry in China has basically been under state ownership and control. At present, the state sector owns all transmission and distribution (T\&D) networks and accounts for more than $90 \%$ of power generation. Generation, transmission and distribution of electricity in different areas are vertically integrated and under the management of a public monopoly. State-owned power enterprises used to be fully responsible for the construction, management and operation of the electric power systems.

Over the last two decades, the regulatory and industry structure of the power industry has been restructured several times. From the Ministry of Water Resource and Electric Power (before 1988), it became the Ministry of Energy (1988-1993), then the Ministry of Electric Power (1993-1997), the State Power Corporation (SPC) (1997-2002), and the 
present structure (since 2002). In 2002, the State Council announced a major restructuring programme for China's power industry. Since 1997 the SPC has been divided into separate regional transmission companies and required to divest itself of its generating facilities. Two major regional transmission companies were formed, one in the south and the other in the north. The generating assets of the SPC were transferred to five independent generating companies. The divestiture was aimed at reducing the dominant power of the SPC and increasing the competitiveness of other smaller private or state-owned power enterprises in the power generation market. The proceeds from privatising the generating assets of the SPC can be used to finance the future expansion of T\&D networks.

To improve operating efficiency and to facilitate the introduction of market mechanisms into the power industry, the Chinese government aims at achieving a nationwide network interconnection. With the completion of the Three Gorges HydroElectric Power Station in 2008/09, three strong trans-regional interconnected power networks will be formed, based on the existing six inter-provincial grids. These are: Northern China Interconnected Power Network, Middle China Interconnected Power Network, and Southern China Interconnected Power Network. These three transregional interconnected power networks will be further interconnected to form a nationwide power network. This nationwide interconnection can help to optimise generating capacity, improve reliability of supply, and facilitate peak load adjustments in different areas.

Critical issues in developing the energy sector

The development of the energy sector is of fundamental importance to China's economic growth. An insufficient supply of energy will constrain the growth of the other industries. Unreliable supply and high prices will discourage the wider use of consumer appliances and automobiles. High energy prices will also decrease China's competitiveness. On the other hand, energy production creates an adverse impact on the environment.

A persistent supply-demand gap

Despite the rapid growth in energy production in the last two decades, supply and demand still lag behind economic growth. Since 1993, China has become a net importer of oil, and the amount of imported crude oil has increased over time. Increasing reliance on foreign supply will make China vulnerable to fluctuations in world oil markets and in the face of international political instability. Increases in import prices of oil will adversely affect China's balance of payments position and domestic prices.

The growth of capital investment in the power industry has lagged behind the country's economic growth ${ }^{11}$. The problem of power shortages in China has become more acute since 1979. In the 1970s, power shortages only occurred in a few cities in the eastern and southern parts of the country. Shortages began spreading to the north and the west in the last twenty years. Since the industrial sector consumes around $70 \%-75 \%$ of China's electricity, a continuing growth of this sector is requiring China to speed up the expansion of the electric power sector. Power shortfall has become the bottleneck for economic development. And this has had the adverse effect of retarding industrial production.

30 The introduction of various reform policies in recent years has improved the quality of coal and oil products. China's generating capacity has also increased substantially. Despite achievements, however, the problem of power shortages still exists in many 
regions in eastern and southern China. The reasons for shortages are numerous, and are interlinked. These include artificially low electricity tariffs, insufficient capital investment in the electric power sector, and insufficient capacity to produce generating equipment.

Low energy efficiency

China's great reliance on coal fuel has lowered the energy efficiency of the country. Due to the wide use of low-quality coal for power generation and domestic use, the thermal efficiency of China's energy sector is lower than that of many other developed countries. The reduction in the use of low-quality coal and improvement in the energy efficiency of coal-fired plants are indeed of vital importance to China's energy efficiency.

The potential of China's hydro-electric resources is great, equivalent to $380 \mathrm{GW}$ of generating capacity, but only a quarter of it (i.e. 79GW) is being exploited. Apart from the low exploitation rate, there is a problem of transmitting hydro-electric power from the western part of the country to the eastern coastal regions. In recent years, increased efforts have been made in carrying out the high voltage (330/500 kV lines) transmission projects to serve as the backbone of the regional networks. With high voltage transmission lines in place, electric power can be transmitted from hydroelectric power stations in the western part of China to the east during wet seasons; and this is fed back from thermal power plants in the east during dry seasons. Similarly, oil and gas in west China can be transmitted to north China and the eastern coastal regions by constructing pipelines.

4. Carbon dioxyde (CO2) emissions in 2001

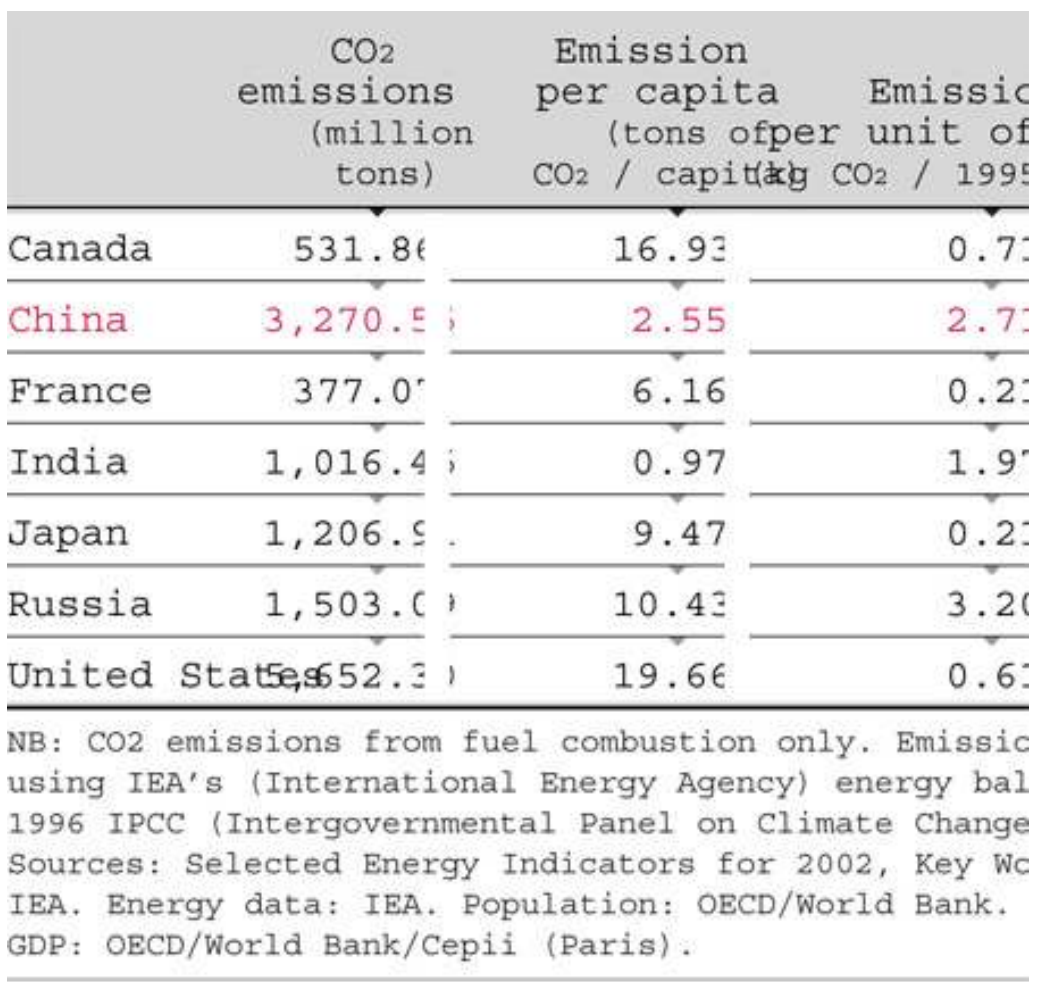

China's biggest consumer of coal is the electric power industry. The reliance on coalfired thermal plants has caused serious local and regional pollution problems. Coal 
combustion leads to the emission of certain harmful chemicals such as particulates (TSP), nitrogen oxide (NOX), carbon dioxide (CO2), and sulphur dioxide (SO2). These pollutants not only affect the living environment of China, but also neighbouring countries including Korea and Japan. China needs to design incentive policies to promote energy efficiency and renewable energy development, and enhance its cooperation with the international community ${ }^{12}$.

The level of $\mathrm{CO} 2$ emissions in China, both in terms of total emissions and emissions per unit of GDP, are very high (see Table 4). But because of the large population, emissions per capita currently remain low. However, as the Chinese economy continues to grow at a rapid rate, it is expected that the increase in energy use will have a significant environmental impact on the global economy. By 2025, China's CO2 emissions are forecast at around $18 \%$ of the world's total emissions. Since China and India are lowincome developing countries with a large population, the Kyoto Protocol does not apply to them as to developing countries. However, as these two populous countries continue to develop, it is expected that there will be increasing international pressure on them to improve energy efficiency. Both countries need to exert considerable efforts to reduce greenhouse gas emissions.

Artificially low electricity tariffs

Low energy prices have been identified as the root of China's energy shortage problem. In recent years, coal and oil prices have been allowed to increase to reflect world prices. In the electric power sector, however, a true pricing reform has yet to come. The standard nationwide electricity tariffs in China remained basically unchanged from the 1950s to the early 1980s and were far below the costs of production. Low electricity prices forced power companies into deficit, which had to be financed by large borrowings and government subsidies. Capital funds were made available from the government and state banks at low cost. Historically, coal was sold to the power sector at subsidised prices, sometimes at half, or even less than half, of the cost of production. For existing thermal power plants, low financing costs and subsidised coal prices allowed power companies to charge low tariffs.

An artificially low level of electricity tariffs inhibited incentives for foreign investment and energy conservation. As China was transforming into a market economy, reform of energy pricing was called for in order to eliminate the energy shortage and encourage energy conservation. To encourage foreign investment in the power sector, the formulation of a unified electricity pricing policy, pricing principles and calculation formulae are of particular importance.

Since the early 1980s, progress has been made in raising energy prices to market levels. In 1985, electricity tariffs were raised throughout the country. Local areas were allowed, for the first time, to raise tariffs to cover rising costs of fuel and transport. The increases in tariffs stimulated capital investment in the power sector. The State Council issued a policy, entitled "on encouraging investment in the power industry and executing multi-tier electricity tariffs", which was aimed at encouraging foreign firms to invest in the power industry ${ }^{13}$.

The Chinese government has introduced other pricing reform policies to attract foreign investment, for the purpose of both reducing power shortages, and preventing stateowned power enterprises from suffering persistent losses. In 1991, a "high-in and highout" policy was introduced, which allows electricity tariffs to fluctuate according to fuel costs and other production costs. Significant tariff increases were granted in the 
early 1990s. From 1990 to 2000, average power tariffs tripled by the equivalent of an increase of $12 \%$ per annum. Yet the increase in electricity prices has been much lower than that for petroleum products (see Figure 5). Electricity tariffs remain below the true cost of production. Occasionally, the Chinese government has to reduce the pace of price reforms for fear of stimulating inflation. State-owned power enterprises have complained that they are not allowed to raise tariffs to reflect the increases in fuel costs. The result is a deterioration in their financial performance. Artificially low tariffs and inadequate returns continue to deter foreign investment in China's power sector.

Insufficient capital investment

It was estimated that the domestic capital available for power development falls short of projected needs by about $20 \%-30 \%$. The gap has to be filled by foreign capital. The imbalance between planned expansion and domestic capacity has also created a big market for foreign manufacturers of generating equipment. In the 1980s, the Chinese government repeatedly used foreign investment opportunities in the equipment market to secure technical transfers from multinational corporations. Foreign companies hoped that by assisting the upgrading of power equipment, they would be in a better position to gain access to the vast potential market in China.

In the early 1990s, China opened its doors to foreign direct investment in electricity generation, with the aim of reducing electricity shortages and enhancing productivity of power plants. However, because of persistent institutional barriers, the actual volume of foreign direct investment throughout the 1990s fell short of the target by a substantial margin ${ }^{14}$. Foreign investors often find it time-consuming to negotiate a power project. They often face difficulties in securing a loan from banks, as the Chinese party is reluctant to guarantee returns. The government approval process is not transparent, and when growth in demand for electricity slows or when a competitive bidding system for power dispatch is introduced, there is the risk that the conditions of power purchase contracts can default. In recent years, because of the increased uncertainties and risks associated with power sector restructuring and new regulations, foreign firms have held back investment in China's power sector.

41 Another major reason accounting for the low energy efficiency of China's power sector is the government's foreign investment policy. In China, large power projects require the approval of the State Council. Due to the red tape involved in the large infrastructure projects, many foreign lenders and investors would rather invest in smaller projects that only require local government approval. The policy of encouraging small power plants has sacrificed scale economies in power generation and has led to the prevalence of small, inefficient power plants. Many of these small power plants are not equipped with modern pollution control devices. To revert this policy, the Chinese government is now encouraging the construction of large thermal power plants and closing down obsolete smaller ones.

42 As China's economy expands rapidly, the conditions for financial assistance from multilateral development banks, such as the World Bank, the Asian Development Bank, and foreign government export credit agencies, will become more stringent. Consequently, China needs to attract considerably more private investment from abroad and to raise substantial loans in the international capital markets. To increase foreign direct investment in the power sector, there is a need for the chinese government to improve the institutional climate for foreign investment, streamlining 
the approval process by avoiding unnecessary time-consuming and arbitrary procedures.

Unproductive state-owned enterprises

The system of the state-owned enterprises (SOEs) was established after 1949. Since then, the state sector has dominated the Chinese economy and suffered chronic problems of mounting losses, huge borrowings, and low productivity. The debt-asset ratio in the state-owned sector is too high. It has been suggested that if "hidden losses" are taken into account, the ratio might be as high as $85 \%$, and losses have been concentrated in some sectors including coal mining, oil and gas, and machinery ${ }^{15}$. The SOEs had to shoulder the social responsibility of creating employment, and providing employees with various kinds of fringe benefits and service facilities like housing, education and medical care. As a result of this social burden, energy enterprises in China were grossly unproductive as compared with their counterparts in other countries. Some estimates have suggested that surplus workers in the state sector, including the energy sector, could be $30 \%$ of the total workforce ${ }^{16}$.

In the last decade, the Chinese government has introduced various reforms to raise the productivity of the state sector. In 1988, the National People's Congress enacted the Law on Industrial Enterprises Owned by the Whole People. Under this legislation, the SOEs were granted independent legal status and the right to make their own managerial decisions to protect them from any government intrusion. They were also required to take full responsibility for profits and losses and practise independent accounting. A Bankruptcy Law was also created, which allows chronically mismanaged and inefficient enterprises to be closed down. But the number of enterprises that actually went bankrupt remained very small until 1994. After 1994, the central government began actively to enforce the law.

In July 1994, the first Company Law in China became effective. The primary purpose of the Company Law is to standardise and modernise enterprise law for both the state and the non-state sector. It was designed to restructure the SOEs using international capitalist models of the corporate form. Under the new legislation, the SOEs are treated as independent legal entities separate from the state, with the power to manage their assets. The Company Law contemplates several kinds of corporation including limited liability, wholly state-owned joint stock, or majority state-owned joint stock company. A joint stock company can issue shares, which can be listed on China's two stock exchanges (Shanghai and Shenzhen), or on a foreign stock exchange ${ }^{17}$. Later in 1995, the government introduced the policy of "grasp the large and release the small", which aimed at turning several hundred large SOEs into world-class businesses, while allowing the small SOEs to go bankrupt.

In recent years, the SOEs in the energy industry have been corporatised and converted into "independent corporations", which are responsible for the economic management and planning of their respective regions. At the provincial level, energy corporations have been formed to take over the business functions of the former power bureaux. Following this restructuring, all energy corporations, whether at the regional or provincial level, now operate under commercial principles and no longer receive large government subsidies. To obtain new capital for expansion, some large energy corporations have issued shares to private shareholders and publicly traded shares are available to private investors, domestic or foreign. It is hoped that corporatisation and 
listing on the stock market will create greater pressure on the SOEs in the energy sector to improve productivity.

Prospects for the energy sector

Under the current Tenth Five-Year Plan, the Chinese Government plans to form seven to nine enterprises with an annual coal output exceeding 50 million tons. Major oil and gas companies are in the process of consolidation to raise competitiveness to face impending foreign competition. For the power industry, however, the restructuring process has been delayed by opposition from parties with vested interests. In future, energy reforms in China will focus on power market restructuring and the creation of appropriate governance structures to maintain a level playing-field for energy companies to compete in the newly restructured market.

Foreign investment

To meet China's future capacity requirements, the government announced that at least $20 \%$ of this development would still be financed from abroad. However, the proportion of foreign capital in total capital investment in recent years has remained low at about $10 \%$. In order to create a suitable regulatory framework governing foreign investment in the power sector, the Electricity Law confirms the power of the SDPC in the determination of specific tariffs. Although the Law allows that costs shall be reasonably covered and returns reasonably determined, it does not clarify the entire approval process and the standards for determining permissible rates of return. In 2001, the SDPC issued a document (No. 701) on the standards for determining electricity tariffs and permissible rates of return. According to the document, electricity tariffs should be based on long-run average costs and the permitted rate of return should be set at a risk premium above the interest rate on a five-year loan. However, the document did not provide clear guidelines for determining the risk premium.

To speed up the project approval process, new rules and laws related to foreign financing of energy projects have been issued. The most significant one is the BOT (built-operate-transfer) Notice promulgated in 1995. The Laibin B Thermal Power Plant in Guangxi became the first power plant of this kind under the BOT Notice. In the past, power projects in China were mainly based on the joint-venture model, governed by the Sino-foreign Co-operative Joint Venture Law. The BOT Notice provided a new model of contracting, which is based on established international BOT structures for pilot BOT projects that receive the requisite central-level approvals. The Notice then lays out the central-level approval process required for such pilot BOT projects.

The BOT model is designed to attract foreign investment to finance power projects in economically less developed regions of China. However, in practice, foreign investors still encounter a number of contractual problems when trying to negotiate BOT power projects with the Chinese authorities. Foreign companies have to face the risk of selling power to a few state firms that might exercise monopoly power to lower the purchase price, or change the power purchase agreement unilaterally. Given the slowing of economic growth and power consumption, foreign investors and local government are less interested in BOT projects in power construction. The Chinese government should continue its efforts to design clear rules and governance structures to protect foreign investment.

Governance structure and enterprise reform

51 In the reform process of the energy industry, there exists a problem in the delineation of the responsibilities of central and local government. Provincial governments have 
gradually increased their influence over energy enterprises while the central government has lost its ability to enforce regulations and policy decisions. Regulatory staff at the local level are usually employed by local government but to enforce regulations imposed by the central government. The policy and regulatory functions of various commissions in the State Council and local government agencies are not clearly defined. Some are reluctant to give up responsibilities and compete for resources. One obvious example is the poor enforcement of safety regulations and the closure of illegal mines due to conflicts of interest between local and central government ${ }^{18}$. Hence, it is important for the Chinese government to provide a clear regulatory framework governing the energy sector. It has been proposed that China can follow the federal system in place in the United States and Canada, in which regulatory policies of the central government (such as safety standards and inter-provincial issues) and local agencies are clearly defined and enforced. A unified regulatory authority governing all energy matters at the state and provincial levels should also be considered.

52 A similar problem of governance structure exists at the industry and enterprise levels. Despite restructuring of energy industries in recent years, the freedom of state-owned energy enterprises in the participation of domestic and foreign competition is not clear. For example, it is not clear whether domestic oil companies can expand to the territories of other companies by mergers and acquisitions. There is also a lack of clear policy guidance for domestic oil companies on acquiring foreign assets. In the absence of clear anti-monopoly rules and guidelines for mergers and acquisitions, managers of energy companies may act for their best interests at the expense of public interest. Collusion or co-operative agreements between local and foreign competitors are possible. Without a clear institutional framework to delineate regulatory authorities to govern competition in the energy market, monopoly power can easily develop.

Corporatisation of state-owned power enterprises may exacerbate the agency problem in the energy sector. Enterprise groups continue to allow the government to play a role in their operations despite efforts to free enterprises from government intervention. At present, large-scale SOEs still lack independent corporate governance such as a board of directors with the power to appoint senior management. Senior posts are appointed by the government officials who might have close relations with the enterprises. The practice of simultaneous employment in government, on boards of directors, and in enterprise groups, hampers the intent and purpose of reforms that are meant to separate enterprise from government functions. Without appropriate corporate governance, enterprise autonomy may accelerate the loss of state assets and provide more opportunities for rent-seeking activities.

To avoid undue political influence on management, it is argued that the government has to divest its shareholding in large-scale energy enterprises. Ownership and income rights of shareholders have to be defined clearly, so that the contractual parties are protected and management cannot use profits from listed companies to subsidise other unproductive businesses. There is also a need to tie the compensation of managers of corporatised enterprises to their performance. One alternative is to diversify the ownership of a state enterprise into the hands of several large minority shareholders to avoid monopoly control; this will create enough incentive for each individual shareholder to monitor its performance ${ }^{19}$. To sum up, in the process of transforming energy enterprises from a state entity to a legal entity, the roles, ownership rights, and 
relations between the state, industrial sectors and enterprises should be redefined clearly.

Impact of WTO membership

55 As a member of the World Trade Organisation (WTO) since December 2001, China has to follow the international rules governing competition and trade. With China's entry into the WTO, the energy industry is exposed to the whim of the world market. Certain changes to the competitive environment in the oil and gas markets within China are anticipated. These changes include the gradual liberalisation of the retail business and wholesale market for oil products to foreign competition, gradual reductions in tariffs on imported oil products, and eventual removal of quotas and other non-tariff barriers for imports and exports of oil products. To the oil incumbents, China's entry into the WTO would intensify domestic competition. In the post-WTO environment, foreign oil and power companies pose severe competitive pressure on the incumbents in China. The incumbents have to form strategic alliances with foreign partners to maintain market share.

But there is a positive side to China's WTO entry. For example, eventual removal of export quotas for textiles and lowering of import prices of consumer durable, particularly imported cars, will raise demand for oil products. At the same time, WTO entry would encourage Chinese energy enterprises to explore opportunities to acquire assets overseas. Overseas acquisitions would be key to the future growth of China's major oil companies.

The electric power industry in China supports massive employment: providing auxiliary services in design, construction, installation and maintenance of power facilities and equipment. Many of these auxiliary companies rely heavily on the "mother" company for preferential financial and business support. Being in the WTO will have a significant impact on these enterprises. China's opening to foreign companies will allow the importation of advanced technology and skills. Well-equipped companies will survive, but others, especially those that rely heavily on their "relationship" with and protection from the "mother" company will find it difficult to continue.

State-owned energy enterprises have to develop a number of strategies to prepare for the WTO challenge. To be survive, the energy industry will have to undergo severe enterprise reform. This will require trimming of inefficient operations, demolishing monopolies, and strengthening core businesses. The issue of unemployment will need to be handled with sensitivity particularly as the social security system in China remains under-developed.

The energy sector in many countries has undergone substantial changes in ownership and organisational structure in the last decade. Apart from corporatisation and privatisation of electricity and gas industries, competition has replaced the monopoly in the energy sector. In China, major SOEs in the energy sector have been corporatised and are operating according to commercial principles. Some have already issued shares to public and private investors. The Chinese government has, for energy groups, mandated a separation of regulatory from business functions.

60 In recent years, in order to attract foreign investment and to improve the efficiency of the energy sector, the Chinese government has introduced various reforms. The aims of these reforms are to raise the productivity of the state-owned energy sector, to 
overcome the constraints in energy consumption and production, and to establish a number of large enterprises to compete in the national and world markets.

Given the size and strategic importance of the energy sector, China cannot directly follow the path of privatisation and industry restructuring experienced in Western countries. With more than ten million workers employed in the energy sector, any radical reforms will inevitably bring with them serious unemployment problems and consequential social unrest.

Furthermore, the reform process needs to be gradual. A speedy introduction of competition might jeopardise the financial position of energy enterprises, which already have high debt-asset ratios. Energy endowment of the country must be taken into account. Until China builds up its hydro-electric power, oil and gas resources, the country will continue to rely on coal fuel and coal-fired plants that are heavy polluters. Open market competition might prolong the retirement of old and inefficient plants, dwarf the growth of domestic firms, and discourage the development of new energy projects. Reform of the energy sector must take into account both capacity constraints and environmental impact.

\section{NOTES}

1. The author would like to thank Alice Shiu for providing assistance in statistical analysis and Andrew Tam for providing information about recent developments in China's energy market. Thanks are also due to Andrew J. Narwold and Shelton H. Brown for their valuable comments on the early draft of the article. The work described here was supported by research grants from the Hong Kong Polytechnic University (Project A/C Code: G-T196; B-Q505) and the Research Grants Council of Hong Kong (CERG 01-02, PolyU5213/01H).

2. Jonathan E. Sinton and David G. Fridley, "What Goes Up: Recent Trends in China's Energy Consumption", Energy Policy, Vol. 28, No. 10, 2000, pp. 671-687.

3. Daniel Todd and Zhang Lei, "Ports and Coal Transfer: Hub of China's Energy Supply Policy”, Energy Policy, Vol. 22, No. 7, 1994, pp. 609-622.

4. Elspeth Thomson, "Reforming China's Coal Industry", The China Quarterly, Vol. 147, 1996, pp. 726-750.

5. Mehmet Ogutcu, "China and the World Energy System: New Links", The Journal of Energy and Development, Vol. 23, No. 2, 1998, pp. 281-326.

6. Philip. Andrews-Speed, Stephen Dow and Zhiguo Gao, "The Ongoing Reforms to China's Government and State Sector: the Case of the Energy Industry", Journal of Contemporary China, Vol. 9, No. 23, 2000, pp. 5-20.

7. China Electric Power Press, Energy in Energy for 50 Years, Peking, China Electric Power Press, 2001.

8. See Alain Sepulchre, "Energy and Globalisation: Oil and Gas in China", China Perspectives, No. 54, July-August 2004, pp. 17-28. 
9. Haijiang Wang, “China's oil policy and its impact”, Energy Policy, Vol. 23, No. 7, 1995, pp. 627-635.

10. The government now publishes a benchmark price for different grades of crude oil monthly, instead of twice a year as previously, with reference to international market prices. As for natural gas, the SDPC publishes production targets and formulates an annual gas guidance supply plan.

11. Ming Yang and Xin Yu, "China's Power Management", Energy Policy, Vol. 24, No. 8, 1996, pp. 735-757.

12. Zongxin Wu et al., "A Macro-assessment of technological options for $\mathrm{CO}_{2}$ mitigation in China's energy system", Energy Policy, Vol. 22, No. 11, 1994, pp. 907-913; John Byrne, Bo Shen and Xiuguo Li, "The challenge of sustainability: Balancing China's energy, economic and environmental goals", Energy Policy, Vol. 24, No. 5, 1996, pp. 455-462. 13. Philip Andrews-Speed, Stephen Dow, Aijuan Wang, Jin Mao and Bin Wei, "Do the Power Sector Reforms in China Reflect the Interests of Consumers?", The China Quarterly, Vol. 158, 1999, pp. 430-446; and X. Liang, L. Goel, "The Achievements and Trend of Tariff Reform in China - The Experience in Shandong Province", Utilities Policies, Vol. 6, No. 4, 1997, pp. 341-348.

14. Allen Blackman, Xun Wu, "Foreign Direct Investment in China's Power Sector: Trends, Benefits and Barriers", Energy Policy, Vol. 27, No. 12, 1999, pp. 695-711.

15. Russell Smyth, "Should China be Promoting Large-scale Enterprises and Enterprise Groups?", World Development, Vol. 28, No. 4, 2000, pp. 721-737.

16. For detailed discussion of the problems facing the state sector, see Russell Smyth, "Enterprise Bankruptcies and the Restructuring of China's State-owned Sector: A Review of Some Recent Problems and Prospects for Future Success", China Information, Vol. 13, No. 4, 1999, pp. 66-82; Tim Wright, "Competition and Complementarity: Township and Village Mines and the State Sector in China's Coal Industry", China Information, Vol. 14, No. 1, 2000, pp. 113-130; and Leong H. Liew, "China's Economic Reform Experience: The End of a Pareto-Improving Strategy", China Information, Vol. 14, No. 2, 2000, pp. 129-168.

17. Daniel C. K. Chow, "An Analysis of the Political Economy of China's Enterprise Conglomerates: A Study of the Reform of the Electric Power Industry in China", Law and Policy in International Business, Vol. 8, No. 2, 1997, pp. 383-433.

18. International Energy Agency, Coal in the Energy Supply of China, Paris, OECD/IEA, 1999.

19. Tian Zhu, "China's Corporatization Drive: An Evaluation and Policy Implications", Contemporary Economic Policy, Vol. 17, No. 4, 1999, pp. 530-539.

\section{RÉSUMÉS}

Since 1978, China's rapid economic development has brought about a growing demand for energy. The Chinese government has introduced a number of reform policies to attract investment, including foreign exchange reform, pricing reform, legal reform, and enterprise reform. To further improve the performance of the energy industries, the government has 
embarked on several programmes of industry restructuring in recent years. These programmes will have significant effects on the energy sector in the coming decades. This article reviews critical issues that pertain to the development of China's energy sector and assesses the sector's future. 